ВПЛИВ СІМЕЙНОГО ВИХОВАННЯ НА ФОРМУВАННЯ ЦІННІСНИХ ОРІЄНТАЦІЙ ПІДЛІТКІВ

\title{
THE IMPACT OF FAMILY UPBRINGING ON THE FORMATION OF TEENAGERS' VALUES
}

\begin{abstract}
у статті висвітлено результати дослідження, спрямованого на аналіз рівня впливу сімейного виховання на формування ціннісних орієнтацій підлітків, що зумовлене підвищенням впливу батьків на підлітка. Саме у сім'ї складаються уявлення дитини про добро і зло, порядність, поважне ставлення до матеріальних і духовних цінностей, тому більшістю дослідників сім'я розглядається як середовище, де відбувається вироблення і прийняття цінностей молодим поколінням. Відповідно до поставленої мети було підібрано ряд методик, таких як Тестопитувальник поведінки батьків і ставлення підлітків до них, розроблений Е. Шасрером, Методика PVQ «Портрет чінностей» (за Ш. Шварцом (в адаптації І. Семків)), методика «Дитячо-батьківські стосунки у підлітковому віці» (за І. Марковською). Визначені методики дають можливість встановити показники иінностей у батьків та дітей, рівень впливу виховання батьків на ціннісні орієнтації підлітків, фоактори виникнення і розвитку сімейних конфоліктів, виявити установки поведінки й методи виховання батьків та визначити, якими бачать своїх батьків підлітки, а також вивчити взаємодію батьків з дітьми: «невимогливість - вимогливість», «м'якість - суворість», «автономність - контроль», «емоційна дистанція-близькість», «відкидання-прийняття», «відсутність співпраці - співробітництво», «незгода - згода», «непослідовність - послідовність», «авторитетність батьків» та «задоволеність відносинами 3 дитиною (батьком/матір'ю)». Отримані результати дослідження дали змогу встановити, що на ціннісні орієнтації підлітків частково впливає виховання батьків. Саме сімейне виховання як компонент унікального середовища дитини, певною мірою формуючись під впливом індивідуально-типологічних особливостей як підлітків, так і батьків, впливає на ціннісні орієнтації підлітка. У сім'ях, у яких існує схожість сімейних поглядів на життя та сприйняття один одного, виховання батьків більше впливає на чіннісні орієнтаuіï їхніх дітей, а в сім'ях, в яких є різне ставлення та несприйняття один до одного,
\end{abstract}

виховання батьків не впливає на ціннісні орієнтаuії їхніх dimeŭ.

Ключові слова: батьки, виховання, підліток, сім'я, ціннісні орієнтації.

The article highlights the results of a study aimed at analyzing the impact of family upbringing on the formation of adolescents' value orientations, which is caused by the increased influence of parents on adolescents. The child's ideas about good and evil, honesty, respect for material and spiritual values are formed in the family. Therefore, most researchers consider the family to be the environment where values are generated and accepted by the younger generation.

In accordance with this goal, a number of techniques are selected, such as: "A parentbehavior test and attitude of adolescents to it", developed by E. Shafer, PVQ Methods "Portrait of Values" (by Sh. Schwartz (adaptation by I. Semkiv)), Methodology "Child-parent relations in adolescence" (by I. Markovskaya). Defined techniques allow to set values of parents and children, the level of influence of parents on adolescents' values, the factors of origin and development of family conflicts, identify the attitudes, behaviors and methods of parenting, and determine how teenagers see their parents, as well as learn about interaction with children: unpretentiousness-demandingness, gentleness-rigor, autonomy-control, emotional distance-closeness, rejection-acceptance, lack of cooperation-cooperation, disagreementagreement, credibility and satisfaction with child relationship (father / mother). The results of the study showed that adolescents'value orientations are partly influenced by parental upbringing. Family upbringing itself, as a component of the unique environment of the child, to a certain extent formed under the influence of the individualtypological characteristics of both adolescents and parents, in turn influences the values of the adolescent. Families with similarities in family views and parental perceptions have more parental influence on their children's values, and families with different attitudes and perceptions do not influence on values of their children. Key words: parents, upbringing, teenager, family, values.
Постановка проблеми у загальному вигляді. Сім'я - це найперший інститут виховання людини. Саме в ній закладаються основи усіх сорер розвитку дитини, формуються громадянські почуття, ціннісні орієнтації, світогляд, ставлення до праці та навколишнього середовища. Діти і батьки - це проблема вічності, яку важливо щоразу вивчати, адже суспільство змінюється, тому і погляди на виховання теж міняються. Потрібно знати, що саме впливає на поведінку та ціннісні орієнтації сина чи доньки, що робити батькам для підтримки хороших взаємовідносин з власними дітьми, дізнаватись, що саме їх турбує, особливо у нелегкому підлітковому віці, адже зі вступом дитини у цей складний період змінюється не лише вона сама, а й усі члени родини, які повинні знайти правильний підхід для запобігання конфрліктам.

Підліток - це ще не дорослий, але вже і не дитина, він шукає своє місце у суспільстві, власне «я», стикається із різноманітними проблемами, які приготував для нього соціум. Саме у цей період відбувається перебудова потреб і мотивів поведінки. Але найбільшою причиною труднощів у цьому віці стають родинні стосунки, суперечності, конорлікти, зокрема через різні погляди на життя, ціннісні орієнтації та стиль виховання. 
Аналіз останніх досліджень і публікацій. У численних наукових дослідженнях (Е. Ейдеміллера, Е. Шафрера, І. Марковської, Л. Собчик, Н. Сологуб, І. Субашкевич та ін.) вивчаються проблеми сучасної родини та здійснюється пошук закономірностей ії фрункціонування. Щоб зрозуміти, яким $є$ теперішній стан сімейних стосунків, потрібно з'ясувати і вивчити систему виховання, стиль життя, уявлення про роль та значення сім"і і ії ціннісні орієнтації. Особливості срормування ціннісної сорери подружжя у своїх працях висвітлювали Л. Долинська, О. Лобашова, А. Харчев. Проблему взаємовідносин батьків 3 підлітками вивчав Н. Атаманчук [1]. Хоча за останні роки в літературі значно збільшилась кількість робіт, присвячених проблемам сім'ї, проте велика кількість важливих питань залишається невивченою. До них можна віднести ціннісну сферу подружжя, а саме індивідуальну ціннісну систему членів сім'ї, вплив виховання на ціннісні орієнтації дитини. 3 огляду на це актуальним $є$ дослідження впливу сімейного виховання на фрормування ціннісних орієнтацій підлітків.

Виділення не вирішених раніше частин загальної проблеми. 3 метою перевірки впливу сімейного виховання на фрормування ціннісних орієнтацій підлітків було використано такі методики: Тест-опитувальник поведінки батьків і ставлення підлітків до них, розроблений Е. Шафрером; методику PVQ «Портрет цінностей» (за Ш. Шварцом (в адаптації І. Семків)); методику «Дитячо-батьківські стосунки у підлітковому віці» (за І. Марковською). Дослідження проводилось серед подружніх пар та їх дітей-підлітків, що є жителями як сільської, так і міської місцевості. Вік опитаних дітей був від 11 до 15, батьків - від 29 до 47 років.

Метою статті $€$ аналіз рівня впливу сімейного виховання на фрормування ціннісних орієнтацій підлітків.

Методика Ш. Шварца PVQ «Портрет цінностей» (в адаптації І. Семків) дозволяє побудувати ієрархічну структуру цінностей особистості або групи людей. Методика складається із десяти шкал, таких як самостійність, гедонізм, конфрормізм, традиція, доброзичливість, універсалізм, стимуляція, досягнення, влада та безпека $[4$, с. 20].

Наступна проведена методика опитувальник «Дитячо-батьківські стосунки» І. Марковської. Ця методика призначена для вивчення взаємодії батьків 3 дітьми. Вона складається із десяти таких шкал: «невимогливість-вимогливість», «м'якість - суворість», «автономність - контроль», «емоційна дистанція - близькість», «відки- дання - прийняття», «відсутність співпраці - співробітництво», «незгода - згода», «непослідовність - послідовність», «авторитетність батьків» та «задоволеність відносинами з дитиною (батьком/ матір'ю)» [2, с. 244].

Ще однією з проведених методик є опитувальник «Поведінка батьків і ставлення підлітків до них» Е. Шафрера, призначений лише для дітей, щоб виявити установки поведінки й методи виховання батьків та визначити, якими бачать своїх батьків підлітки. Методика визначає п'ять таких параметрів, як позитивний інтерес, директивність, ворожість, автономність, непослідовність [3, с. 120].

Виклад основного матеріалу. Згідно з результатами за методикою Ш. Шварца PVQ «Портрет цінностей» (в адаптації І. Семків) (див. рис. 1) у 70\% батьків сільської місцевості на першому місці перебуває влада та універсалізм, а на останньому - безпека та доброзичливість, що вказує на те, що вони прагнуть накопичувати матеріальні ресурси, гроші, але $\epsilon$ активними борцями за справедливість. У $30 \%$ досліджуваних, що проживають в сільській місцевості, найголовнішими цінностями $€$ традиція та самостійність, менш важливою є стимуляція. Це свідчить про те, що люди підтримують звичаї, але бувають залежними від інших.

Жителі міста надають перевагу досягненням та самостійності, але нехтують традиціями (60\%), що вказує на те, що такі люди бажають бути незалежними у своєму виборі та діях. У 40\% містян на першому місці перебуває стимуляція та універсалізм, а на останньому - влада та безпека. Це зумовлено тим, що ці особи люблять подорожувати і ненавидять монотонність у житті. Вони прагнуть досягнути кар'єрного зростання.

Для підлітків сільської місцевості найголовнішими є самостійність та влада (незалежність думок та дій, наявність вибору), проте безпека та доброзичливість $є$ неважливими (60\%). У $40 \%$ жителів сільської місцевості на першому місці $€$ стимуляція та досягнення (стабільність, особистий успіх), а на останньому - традиція. Думка

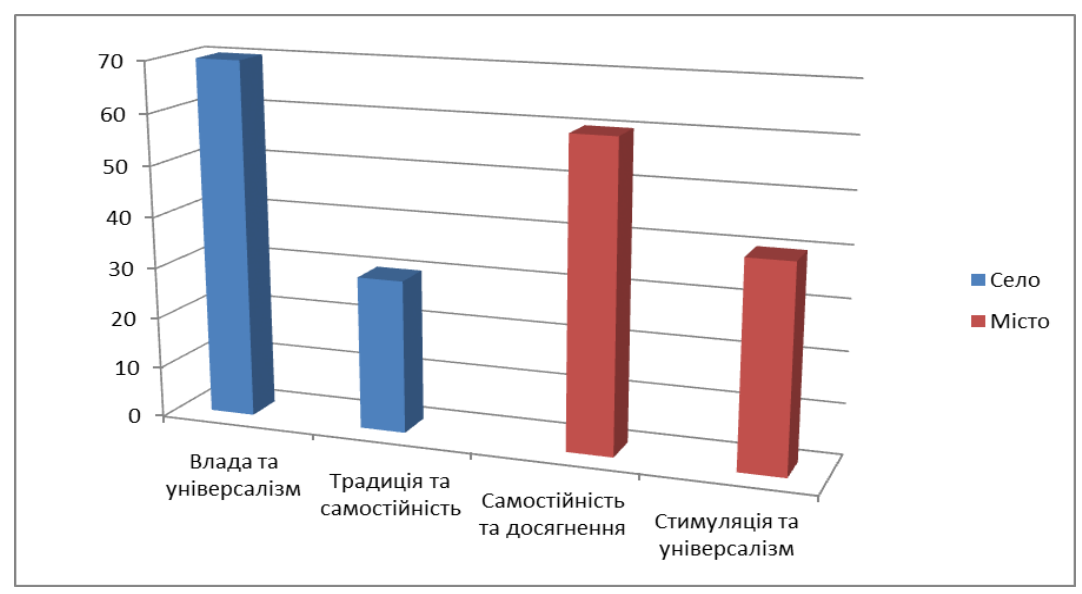

Рис. 1. Ціннісні орієнтації серед подружніх пар (у \%) 
містян $€$ іншою. Для них самостійність та стимуляція $€$ найважливішими (можливість керувати власним життям та схильність до ризику), а традицією та безпекою вони нехтують (80\%). 20\% містян обрали безпеку та універсалізм (гармонію та справедливість ), а досягнення і доброзичливість для них не мають ніякого значення (рис. 2).

Отже, результати опитування за цією методикою показали, що у батьків із сільської місцевості переважає така цінність, як універсалізм, що характеризується вимаганням справедливості та рівності людей. Думка дітей відрізняється, адже для них важливою $є$ самостійність, що характеризується можливістю керування власним життям та рішеннями. Спільною цінністю для всієї сім'ї $€$ влада. До неї відносять прагнення накопичувати матеріальні ресурси, гроші, займати керівні посади. У батьків та дітей, які проживають у місті, цінності є схожими.

Результати опитування батьків та підлітків за опитувальником «Дитячо-батьківські стосунки» І. Марковської (рис. 3) показали, що серед батьків сільської місцевості переважають вимогливість (40\%) та автономний контроль (60\%), а серед міської місцевості - задоволеність відносин (70\%) та м'якість - суворість (30\%).

Як бачимо, серед містян переважають м'якість суворість та задоволеність відносин. Це характери- зує суворість заходів, що застосовуються до дитини, та загальний ступінь задоволеності стосунками між батьками і дітьми. Серед сімей із села переважають вимогливість та автономний контроль, тобто у батьків існує високий рівень вимогливості до дитини та контролю щодо неї.

Взаємодію 3 батьками підлітки оцінили по-різному (рис. 4). Результати вказують, що вимогливість та заперечення переважає у стосунках доньки $з$ матір'ю (80\%). Такі стосунки характеризуються великою вимогливістю матері та відкиданням особистісних якостей і поведінкових проявів дитини. У $20 \%$ сімей переважає емоційна дистанція, яка відображає недооцінку близькості до дитини. Відносини між матір'ю та сином характеризуються відсутністю співпраці, емоційною дистанцією (70\%), результатом якої є порушення відносин, авторитарний, байдужий стиль виховання та небажання ділитися найпотаємнішим. У $30 \%$ сімей більше виражена вимогливість, тобто підліток відчуває, що мама є відповідальною і виконує свої обов'язки щодо виховання.

У відносинах сина з батьком переважає співробітництво та контроль (70\%). Такі стосунки характеризуються рівністю і партнерством у відносинах батьків і дітей та прагненням прищепити їй самостійність. У $30 \%$ сімей панує незгода, що відображає відмінність в поглядах дитини і батька на виховну ситуацію в сім'ї. Стосунки доньки з батьком характеризуються авторитетністю та суворістю (80\%). У $20 \%$ сімей такі стосунки характеризуються відсутністю співпраці, тобто у взаєминах присутня байдужість до виховання.

Опитувальник «Поведінка батьків і ставлення підлітків до них» (за методикою Е. Шафера) дозволила виявити те, як оцінюють методи виховання та самих батьків підлітки (рис. 5). Результати методики показали, що оцінка матері сином характеризується автономністю (70\%), яка виражається несприйняттям матір'ю дитини як особистості. Також, на думку синів, ні емоційна прихильність, ні дружній стиль спілкування не може бути пов'язаний 3 відгородженістю матері від справ сина. У $30 \%$ сімей такі відносини характеризуються непослідовністю, яка виявлена нечіткою лінією виховання та чергуванням таких психологічних тенденцій, як панування сили й амбіцій і покірність (в адаптивних формах), делікатність і альтруїзм та недовірлива підозрілість. Оцінка

\begin{abstract}
батька сином виражена директив-
\end{abstract}
Рис. 3. Взаємодія батьків з підлітками (у \%)

пело

Місто

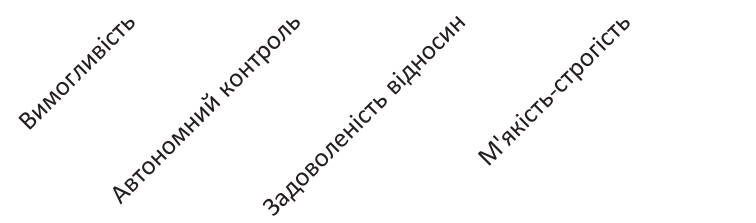


ністю та позитивним інтересом (70\%). Директивність у відносинах із сином батько проявляє у формі тенденції до лідерства шляхом завоювання авторитету, заснованого на фрактичних досягненнях і домінантному стилі спілкування. Його влада над сином виражається у керуванні й своєчасній корекції поведінки дитини, а не в амбіційній деспотичності. При цьому він дуже чітко дає зрозуміти дитині, що заради її благополуччя жертвує деякою наявною в нього часточкою влади. Позитивний інтерес виражається відсутністю грубої сили, прагненням до нероздільної влади в спілкуванні. У $30 \%$ хлопців існують ворожі стосунки, які виражені тим, що батько намагається вимуштрувати свого сина відповідно до прийнятого в даному суспільстві й у даній культурі уявлення про те, якою повинна бути ідеальна дитина, що найчастіше призводить до непосильного навантаження на організм.

Оцінка матері донькою виявлена таким чином: у $80 \%$ сімей виражена директивність та автономність, які характеризуються суворим контролем 3 боку матері, тенденцією до легкого застосування своєї влади, заснованої на амбіціях, а також до неприйняття думки дочки. Автономність матерів виключає яку-небудь залежність від дитини, їі стану, вимог. Заперечуються також будь-які форми турботи й опіки стосовно дочок. Такі матері оцінюються підлітками як поблажливі, невимогливі. Вони практично не заохочують дітей, відносно рідко й мляво роблять зауваження, не звертають уваги на виховання. $20 \%$ дівчат-підлітків оцінюють своїх матерів як непослідовних, тобто матері різко змінюють стиль і прийоми виховання від дуже суворого до ліберального, роблять перехід від психологічного прийняття дочки до емоційного її відкидання. Оцінка батька донькою виражена непослідовністю (80\%), яка характеризує непередбачуваність вчинків і ставлення до дитини. У $20 \%$ дівчат існують ворожі стосунки, які зумовлені надмірною вимогливістю, орієнтованою на еталон ідеальної дитини.

Підсумовуючи результати, можна стверджувати, що у батьків та дітей були виявлені різні погляди та цінності. Для батьків із сільської місцевості характерні такі цінності, як влада, універсалізм, традиція та самостійність, а для їхніх дітей доброзичливість, безпека, стимуляція та досягнення. У батьків і дітей із міської місцевості $€$ такі спільні цінності: самостійність, стимуляція та універсалізм. Однак у батьків на першому місці перебувають досягнення, а для їхніх дітей - безпека.

Висновки. Сімейне виховання як компонент унікального середовища дитини, певною мірою формуючись під впливом індивідуально-типологічних особливостей як підлітків, так і батьків, впливає на ціннісні орієнтації підлітка. Зіставлення отриманих даних вказує, що у батьків і дітей із сільської місцевості існують різні цінності, однак їм притаманне нехтування сімейними традиціями, що спричинене великою різницею у віці, важкою працею, прагненням переїхати у місто та уявленням про навколишній світ. У них немає спільних інтересів, відпочинку. У містян $€$ схожі та відмінні риси, адже у цих сім'ях чітко виражений взаємозв'язок батьків і дітей, існують дружні стосунки та спільні інтереси, вони разом проводять дозвілля. Взаємодія у стосунках така: у батьків переважають м'якість - суворість, задоволеність відносин, вимогливість та автономний контроль, а у їхніх дітей, зокрема хлопця з матір'ю - вимогливість, відсутність співпраці та емоційна дистанція, хлопця з батьком співробітництво і контроль, доньки 3 матір'ю - вимогливість і заперечення, емоційна дистанція, доньки з батьком - авторитетність та суворість, відсутність співпраці. Оцінка батьків дітьми-підлітками така:

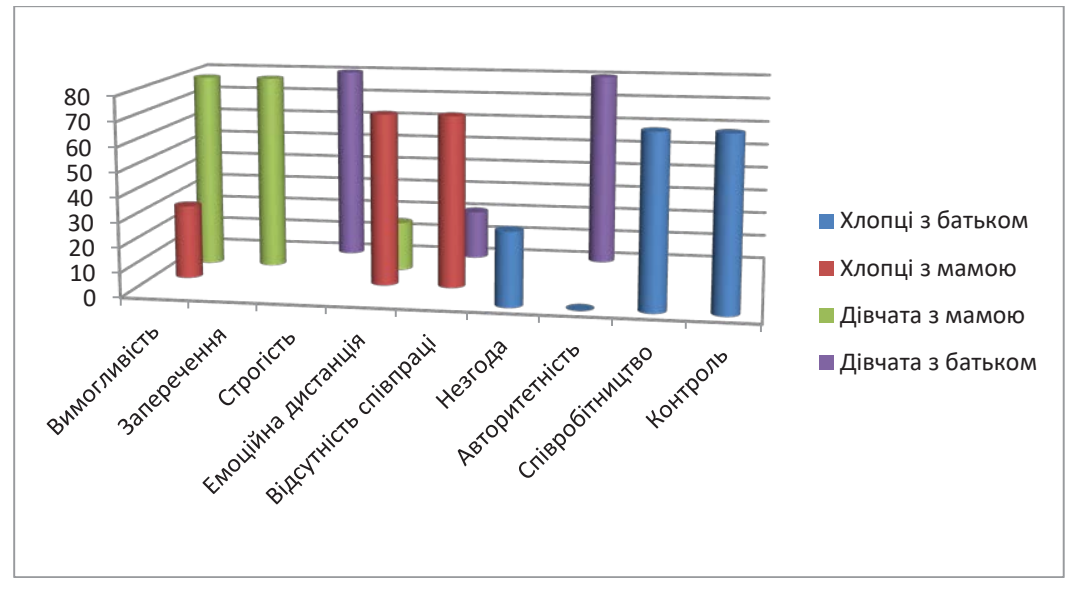

Рис. 4. Взаємодія підлітків з батьками (у \%)

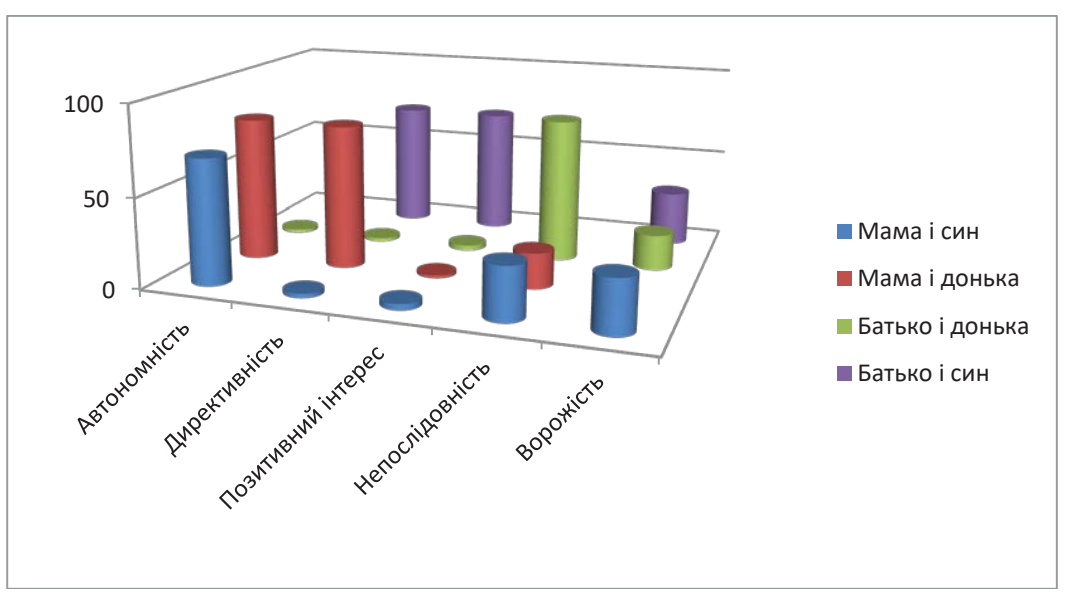

Рис. 5. Оцінка батьків підлітками (у \%) 
оцінка матері сином характеризується автономністю, непослідовністю, оцінка батька сином виражена директивністю, позитивним інтересом, ворожістю, оцінка матері донькою виявлена директивністю, автономністю, оцінка батька донькою виражена непослідовністю, ворожими стосунками.

Отже, з огляду на отримані дані можемо констатувати, що у сім'ях, у яких існує схожість сімейних поглядів на життя та сприйняття один одного, виховання батьків буде впливати на ціннісні орієнтації їхніх дітей, а в сім'ях, в яких панує несприйняття один одного, виховання батьків не буде впливати на ціннісні орієнтації їхніх дітей.

\section{БІБЛІОГРАФІЧНИЙ СПИСОК:}

1. Максименко С.Д. Проблеми сучасної психології. Кам'янець-Подільський : Аксіома, 2013. 852 с.

2. Помиткіна Л.В., Злагодух В.В., Хімченко Н.С. Психологія сім'ї. Навчальний посібник для студентів вищих навчальних закладів. Київ : Вид-во Нац. авіац. ун-ту «НАУ-друк», 2010. $270 \mathrm{C}$.

3. Розов Є.І. Настільна книга практичного психолога. Москва : Владос, 1998. Кн. 2. 144 с.

4. Субашкевич І.Р. Формування ціннісно-смислової сорери студентів педагогічних спеціальностей засобами медіапсихологічних технологій : практ. посіб. Львів : Растр-7, 2016. 60 с. 